\title{
Asylum Seekers Arrived, Elites Occupied the Air
}

\author{
Topics and Interviewees in YLE's Magazine Programmes \\ During the "Asylum-Seeker Crisis"
}

\author{
Annu Perälä \& Mari K. Niemi
}

\begin{abstract}
In this study, we examine the choice of interviewees and discussion topics made by Finland's national broadcasting company YLE during the so-called "asylum-seeker crisis" of 2015 and 2016. The rapid increase in asylum-seekers, combined with deepening political tensions regarding the situation and the entry of a populist anti-immigration party into government, created a challenging environment for the media. This was especially true for YLE, which is committed to political neutrality and cultural diversity. Our data shows that the "crisis" was framed as a crisis hitting Finland and European decision-making rather than as a humanitarian crisis. Despite long-term academic criticism of bias in expert interviewee selection (e.g. the underrepresentation of minority and female interviewees), the media continued to use traditional sources of knowledge. However, in a novel approach for Finland, the media engaged the large-scale involvement of politicians, and especially representatives of the populist Finns Party.
\end{abstract}

Keywords: asylum-seekers, Finland, framing, news source, public expertise

\section{Introduction}

A wide body of literature has demonstrated that the media portrays asylum-seekers and other types of immigrants relatively negatively. Coverage tends to highlight the adverse consequences of immigration and the juxtaposition between "us" and "them" (e.g. Buchanan \& Grillo 2004; Gabrielatos \& Baker 2008; Innes 2010; Kosravinik 2010; Rasinger 2010; McKay et al. 2011; Philo et al. 2013; Balch \& Balabanova 2014; Parker 2015; Blinder \& Allen 2016). When we consider who serves as sources and interviewees, several studies have shown that the media has a tendency to rely on similar kinds of interviewees repeatedly. In general, the use of sources is elite-driven (e.g. Nord \& Strömbäck 2003; Dimitrova \& Strömbäck 2009; Cross 2010), encapsulates a small minority of views (Albæk 2011; Wien 2011; Parviainen 2014; Pitkänen \& Niemi 2016) and tends to be masculine and monoethnic (Ghersetti 2001; Wien 2011; 
Parviainen 2014; Niemi \& Pitkänen 2016; Kulneff \& Cedersjö 2017). At the same time, getting one's voice heard in a public debate is crucial for many political and social groups, as it offers possibilities to defend, legitimise or oppose policy proposals and to make interpretations, offer different perspectives and provide context (Conrad 1999; Tressch 2009; Albæk 2011).

This case study explores the journalistic framing choices in terms of topic and interviewee selection made by the public broadcasting company YLE in unforeseen and unusual circumstances, as Finland faced an "asylum crisis" with a populist party in government. As noted, media source selection and the media coverage of asylum-seekers are widely studied topics; however, our study provides an important update on YLE's journalistic practices on a sensitive topic, following a recent change in the political landscape of Finland: the rise of an anti-immigration party, the Finns Party, into the coalition government for the first time in history, in May 2015.

Growing support for nationalist and populist anti-immigration parties has culminated in these parties' rise to government across several European countries (Balfour et al. 2016), challenging journalists' work practices. Questions of legitimacy and access to public debate are especially crucial for these parties, as they make their way from the margins to the mainstream. In particular, populist parties' stretching of the boundaries of acceptable speech has been followed by repeated accusations of racism and xenophobia (Hellström et al. 2012; Wodak 2015; Jungar 2016; Hatakka et al. 2017).

The asylum-seeker crisis also provided a new contextual environment for the journalistic media. In 2015, the number of asylum applicants to Finland rose from 3,651 to $32,478(+790 \%)$ (Ministry of the Interior in Finland 2016); proportionally the greatest increase in the European Union. Consequently, in relation to its total population, Finland was among the top receivers of asylum-seekers (Eurostat 2016). ${ }^{1}$

The unforeseen development had several immediate real-life implications: numerous new reception centres were founded throughout Finland, new officials were hired to handle the applications and the government tightened immigration legislation (e.g. Saarikkomäki 2018). In civil society, a record high number of people volunteered to help the asylum-seekers; others, in contrast, gathered to demonstrate against the arrival of asylum-seekers in Finland (Niemi \& Perälä 2018). In the most extreme actions, some native Finns formed their own vigilante groups to patrol neighbourhoods, and others even attacked the reception centres accommodating asylum-seekers.

Our data is gathered from YLE's selected magazine programmes. These programmes are widely consumed (Finnpanel 2015) and appreciated (YLE 2015), they are also freely accessible to everyone with a television or radio. As a public broadcaster, YLE is committed to promoting tolerance, cultural diversity, and fairness. ${ }^{2}$ At the same time, as a publicly funded institution, YLE must balance different interests and political pressure. For example, Finn Party politicians have been vocal critics of YLE's news and magazine programmes (for more detail, see Niemi \& Perälä 2018).

Magazine programmes are relatively lengthy live discussions that offer the interviewees more freedom to frame the discussion alongside the journalist than, for example, edited television news stories or newspaper articles do. Without the risk of being edited afterwards, the interviewees can describe an issue in their own words, highlight or downplay certain factors and criticise or offer alternative frames. 


\section{Selecting topics and interviewees as a framing choice}

We divide a news story into (1) agenda setting (i.e. what is covered), and (2) framing choice (i.e. how it is covered; McCombs 2004). In our case, the unprecedented numbers of asylum-seekers arriving in Finland (and elsewhere in Europe) set the agenda for the media. The asylum-seeker situation - also widely referred to as the "asylum-seeker crisis" in the media - met all relevant news criteria: the situation was unfolding in front of journalists' eyes, it was extraordinary and involved conflicting interests, and it had immediate relevance for Finland (Schultz 2007). Thus, the situation was definitely newsworthy, but it was up to journalists to decide how the events were covered and framed - and who was invited to talk and on what topics.

Following Entman's (2004: 5) description of framing as "selecting and highlighting some facets of events or issues, and making connections among them so as to promote a particular interpretation, evaluation, and/or solution", we define framing as a conscious and intentional act used to promote a particular version of reality. Within this tradition, numerous studies have shown the significant importance of the choice and framing of news sources. For example, in the context of immigration, several scholars have criticised the media for being biased and focusing only on the negative sides of phenomena (e.g. Buchanan \& Grillo 2004; Gabrielatos \& Baker 2008; Innes 2010; Kosravinik 2010; Raisinger 2010; McKay et al. 2011; Philo et al. 2013; Balch \& Balabanova 2014; Parker 2015; Blinder \& Allen 2016). Furthermore, asylum-seekers and other immigrants are often disregarded as sources in immigration coverage (Klocker \& Dunn 2003; Gross et al. 2007; Balch \& Balabanova 2011; Philo et al. 2013; Berry et al. 2015; specifically on Finland, see Pietikäinen 2000; Raittila \& Vehmas 2005; Haavisto 2011; Vehmas 2012).

On one hand, framing decisions are often influenced by wider structures, such as ideological leanings, organisational processes and market demands (Vliegenhart \& van Zoonen 2011). News media also have an obligation to include different political and social groups in the discussion (Curran 2002). As noted, as a public broadcaster, YLE has no political leanings; rather, it is committed to fairness and balance. With respect to minority voices, YLE has an internal rule to promote cultural exchange and diversity, although what this means in practice is not specified. There are no official rules regarding source selection; instead, it is something that is learned during journalism studies and in the workplace (Niemi \& Pitkänen 2016).

Several studies indicate that journalists' source selection routines follow fairly similar conventions and produce a rather homogenous pool of sources in terms of ethnicity, gender, expertise and status (e.g. Nord \& Strömbäck 2003; Dimitrova \& Strömbäck 2009; Cross 2010; Albæk 2011; Wien 2011; Niemi \& Pitkänen 2016). Previous case studies show that journalists select researcher sources based on their formal qualifications, status, media skills and former recognisability (Steele 1995; Conrad 1999; Niemi \& Pitkänen 2016; Pitkänen \& Niemi 2016); politician sources are selected based on their status in the political system and their relevance and issue-ownership with respect to the story covered (Buchanan 2003; Horsti 2003; Tressch 2009; Vehmas 2012; Berry et al. 2015). 


\section{Data and methods}

We have gathered data from live broadcasts of YLE's three magazine programmes; one on radio and two on television. The shows are not newscasts; rather, they seek to provide in-depth analyses and context on current affairs. Ykkösaamu airs every weekday morning on YLE Radio 1. The fifty minute show includes two interviews with studio guests (10-20 minutes) and two or three shorter telephone interviews. The morning show Ylen aamu-tv airs every weekday from 6:25 to 9:30 on YLE TV1. It has news broadcasts every half hour, and it incorporates five studio interviews (10-15 minutes) and a varying number of shorter phone interviews or inserts (2-5 minutes). These interviews cover a mixture of current affairs themes and lighter themes, such as entertainment and sports. The other current affairs show included in our data, A-studio, airs three times a week at $9 \mathrm{pm}$ on YLE TV1. Each episode has two or three interviews with inserts (10-20 minutes). The sampling was conducted over a seven-month period from 1 August 2015 to 28 February 2016, when the number of arrivals was above average (Finnish Immigration Service 2017).

The data was collected in a qualitative manner by examining all three sample programmes. All episodes of Ylen aamu-tv and Ykkösaamu were available on YLE's online service Yleareena (areena.yle.fi), and all episodes of A-studio were available on the Finnish Radio and Television Archive. The material selection criteria were that the immediate asylum-seekers situation was the main topic of the discussion and that either the title or description of the discussion in the online archive's platform or the hosting journalist's verbal introduction of the debate was linked to the asylum-seekers crisis. In the majority of the discussions in our sample, the asylum-seekers crisis was the only topic $(\mathrm{n}=221)$, however the data also included discussions about a second or third topic alongside the asylum-seeker theme $(n=45)$. Overall, 266 discussions fitting the criteria were found: 107 in Ykkösaamu, 92 in A-studio and 67 in Ylen aamu-tv.

The interviewees $(n=548)$ were coded based on occupation or role. The coding categories were: (1) academic and other experts (researchers in universities, expert organisations and interest groups), (2) experience experts (asylum-seekers and other immigrants invited to the discussions based on their personal experience, not their profession), (3) civil society representatives (common citizens and representatives of third-sector movements and organisations, excluding charity organisations), (4) journalists, (5) politicians, (6) practitioners (individuals working with asylum-seekers, such as staff in reception centres or charity organisations), (7) officials, and (8) others (e.g. authors). In addition, all interviewees were coded based on their institutional affiliation, gender, ethnicity and party affiliation (in the case of domestic politicians).

The topics and types of discussion were coded. The topics were coded into thematic categories created using a mixed-method of inductive and deductive categories based on previous literature and the data (see Kuckartz 2014). The discussion types were coded into three different categories to determine the hierarchies among interviewees: solo interviews (76 discussions, 76 interviewees), group discussions (77 discussions, 183 interviewees) and short phone interviews or television inserts (113 discussions, 290 interviewees). These different formats gave interviewees varying amounts of leeway and time to express their points (e.g. when interviewed alone, interviewees might have ten or twenty minutes on their own with the journalist in a studio; on the phone, they have only approximately five minutes; and in television inserts, or collections of interviews, 
they have far less than five minutes each).

The study is limited in that our data does not reveal precisely how the interviewees participated in the framing process or the extent to which their views were challenged by other interviewees or by the journalists. Furthermore, we were only able to assess those interviewees who appeared on the programmes, as we had no information about those who were invited but decided to opt out. Immigration is a topic that divides people, and the debate around it is emotional, tense and often aggressive and hostile. This may reduce the number of people willing to publicly participate in the debate.

\section{Results}

The asylum-seeker situation received a remarkable level of coverage in YLE's magazine programmes. During the seven-month monitoring period (August 2015-February 2016), it appeared in 266 discussions. The situation was discussed in approximately every second episode of Ykkösaamu and A-studio and every third episode of Ylen aamu-tv. While the intensity of the reporting probably reflected the exceptionality of the situation, it may have also contributed to producing a crisis atmosphere, albeit unintentionally.

The atmosphere of crisis was apparent in how the situation was framed by YLE's journalists. The crisis was overwhelmingly understood as one of Finnish society - how to pull through, manage and handle a challenging situation - and EU decision-making. It was the crisis of those receiving asylum-seekers, not of the asylum-seekers themselves.

The distribution of topics is presented in Figure 1.

Figure 1. Discussions by topic (per cent)

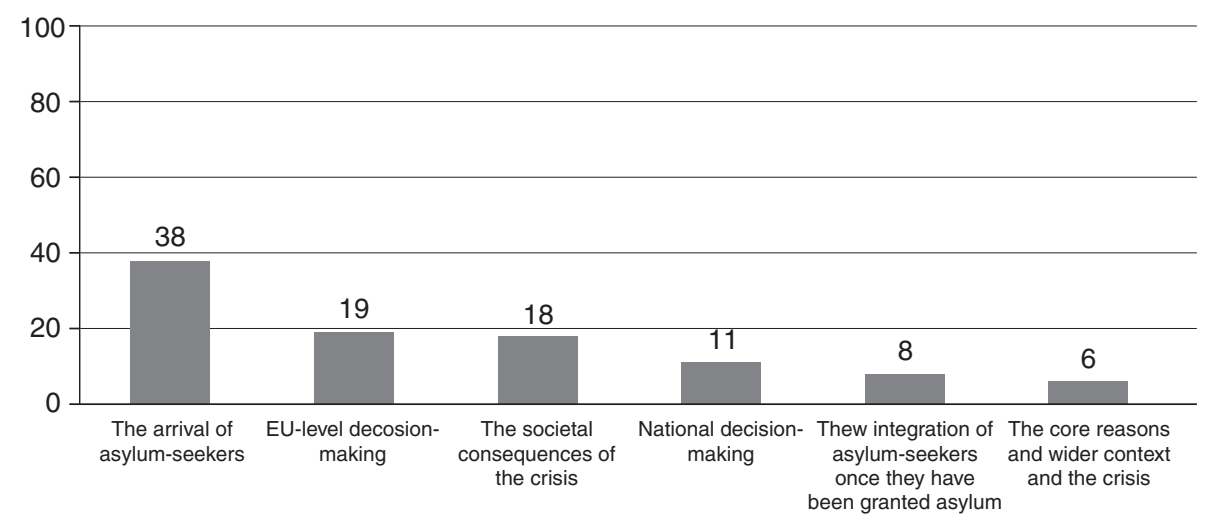

Comments: The programmes analysed were Ykkösaamu, Ylen aamu-tv and A-studio. In total, 266 conversations/ interviews were coded.

In terms of specific topics, the arrival of asylum-seekers was by far the most frequently debated (38\%). It was discussed, for example, in the context of arranging accommodation in reception centres and the functionality of the asylum process. In addition, issues such as asylum-seeker routes and Finland's "receiving capacity" were debated. The second-most-discussed general theme was EU-level decision-making (19\%), and national decision-making (11\%) was the fourth most-discussed. As expected, the public debate and media coverage reflected the Europeanised asylum policy domain (Horsti 2008). 
The societal consequences of the crisis were the third most frequently debated theme $(18 \%)$. In particular, the security threats posed by both asylum-seekers and native Finns was a common topic (mainly sexual harassment and assaults by asylum-seekers, violence and disturbance at reception centres and the controversial vigilante groups of Finns formed to patrol neighbourhoods).

Somewhat surprisingly, the economic consequences of the crisis was the main topic of the discussion on only three occasions. Instead, the debate surrounding the effects of asylum-seekers focused on popular opinion and public discussion concerning the crisis. The cultural effects for asylum-seekers were rarely considered and very rarely discussed with the asylum-seekers themselves. (One exception was asylum-seekers' dissatisfaction with food at the reception centres, which was discussed with a researcher.)

The two least-debated themes were the core reasons and wider context of the crisis $(6 \%)$ and the integration of asylum-seekers once they have been granted asylum ( $8 \%)$. In other words, YLE's magazine programmes concentrated on the immediate crisis and topical issues and rarely tackled the wider context of the crisis or its long-term consequences for society.

Traditionally, immigration has not been very politicised in Finland; prior to the entrance of the Finns Party, the issue was characterised by consensus-seeking rather than party political conflict. However, in recent years, this has changed, and with the rise of the issue on the political agenda, politicians appear more frequently in the media coverage.

Figure 2. An overview of the interviewees by profession (per cent)

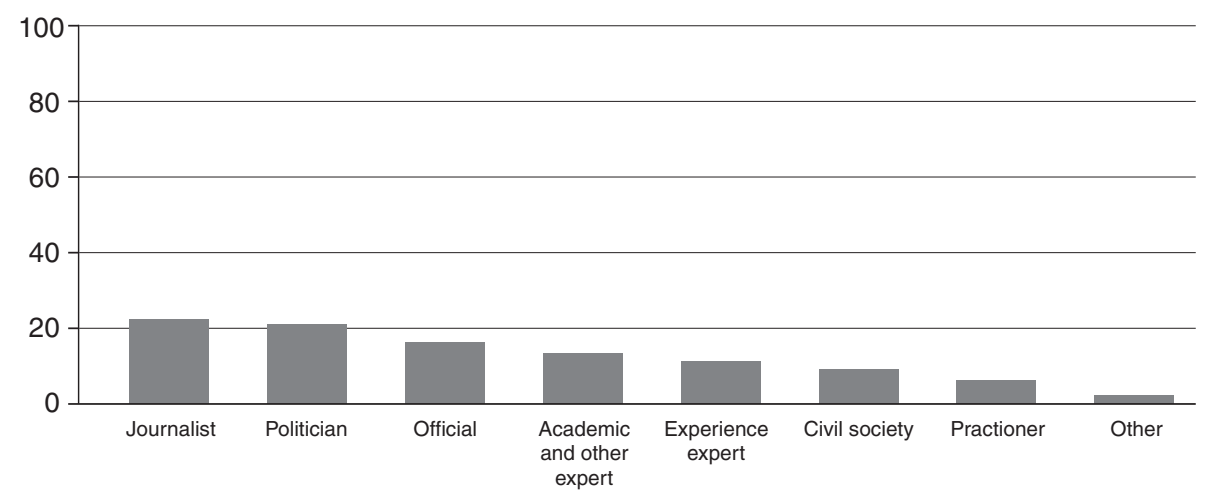

Comments: The interviewees were coded based on occupation or role. Asylum-seekers and other immigrants who were invited to the discussions due to their own personal experiences are coded as "experience experts". In total, 549 interviewees were coded.

As shown in Figure 2, over 70 per cent of interviewees were elite actors: journalists $(22 \%)$, politicians $(21 \%)$, officials $(16 \%)$ and academic and other experts $(13 \%)$. Thus, the proportion of grass-roots interviewees was less than 30 per cent. In media logic, elite sources are the most accredited, authoritative and representative (Hall et al. 1978). Elite sources, however, are by no means a homogenous group with shared interests and policy goals (Schlesinger 1990), and some elite sources fit the journalistic logic better than others (Steele 1995).

That journalists are those interviewed most often may at first glance seem surprising. In reality, however, most of the journalists were YLE's own correspondents in European 
countries and in reception centres throughout Finland, reporting on daily developments through television inserts or short phone interviews. In studio settings, the most-used groups were instead politicians, officials and experts. This is shown in Figure 3.

Figure 3. Interview type by interviewee (per cent)

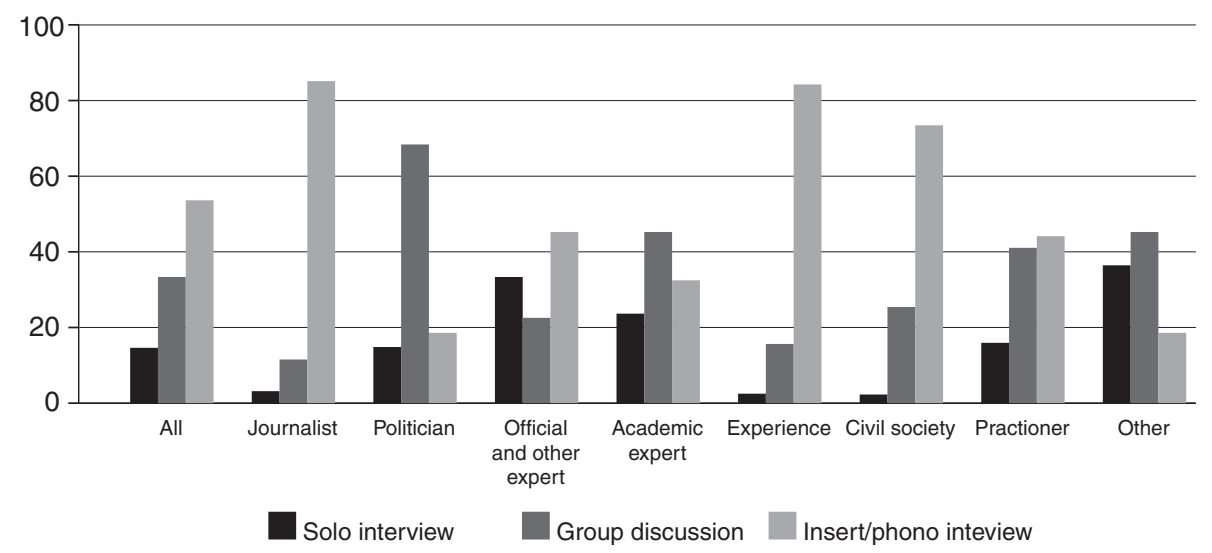

Comments: In total, 549 interviewees participated in 266 conversations/interviews. Among the interviewees, there were 122 journalists, 114 politicians, 85 officials, 74 academics and other experts, 61 experience experts, 48 representatives for civil society, 34 practitioners; only 11 interviewees were coded as "other".

In the context of the immigration debate, the large-scale involvement of Finnish politicians was a novelty (Horsti 2003, 2005; Raittila \& Vehmas 2005; Raittila 2009; Haavisto 2011; Vehmas 2012), reflecting the traditionally de-politicised nature of immigration issues in the country. Compared to many other European countries, Finland has traditionally been very monoethnic; however, in recent years, the number of immigrants has risen significantly, especially when compared to the recent past (Himmelroos \& Leino 2015).

Before the rise of the anti-immigration Finns Party in the late 2000s, immigration politics was consensus-seeking and not claimed by any party (see more Välimäki 2018b). Keskinen (2009) argues that the rise of the Finns Party stopped the consensus phase and brought politicians to the centre of the debate. In the media coverage, voices of the anti-immigration movement (not limited to the Finns Party) now dominate this debate (Horsti \& Nikunen 2013).

As record numbers of asylum-seekers entered Finland, the event quickly became major news, hitting all news criteria. The rapid rise in the number of the asylum-seekers created many concerns and had real-life implications that politicised the issue and demanded political responses. As noted in previous research, the representatives of the governing parties dominated the conversation (Buchanan 2003; Horsti 2003; Vehmas 2012; Yilmaz 2012; Berry et al. 2015).

Of the politician interviewees, 60 per cent were from the prime minister's Centre Party, the Finns Party (second-largest ) or the National Coalition Party (NCP, third-largest). This reflects the power balance inside parliament, both seat-wise and in terms of executive power. ${ }^{3}$ The most-frequently interviewed politician was the interior minister, Petteri Orpo (NCP), who had responsibility for asylum processes. 
Recent studies have suggested that, alongside governing forces, anti-immigration parties have received the most media coverage in relation to immigration topics (Buchanan 2003; Horsti 2003; Vehmas 2012; Yilmaz 2012; Horsti \& Nikunen 2013; Berry et al. 2015). In our case, the Finns Party representatives played an interesting double role as both government representatives and members of the issue owning party, resulting in their overrepresentation as interviewees.

Compared to other parties, the Finns Party had a distinct stance on immigration; thus, their incorporation in the debates could create the false illusion of balance. Two findings suggest this. Firstly, many of the interviewed Finns Party politicians were vocal critics of immigration and belonged to the so-called "anti-immigration wing" of the party. Their opposing stances had more weight than their status, as most were first-time MPs with less than one year of parliamentary experience.

Secondly, Finns Party politicians were particularly in demand in group discussions, in which every third interviewed politician was a Finn Party representative. In solo interviews, the weight of status was more salient, and all solo-interviewed politicians were ministers, party leaders or other notable politicians with official status in parliamentary settings.

Finns Party representatives are always willing to debate immigration, as it is one of the party's main objectives. Although, in general, politicians have great incentive to participate in public debates (Tresch 2009; Cross 2010), for most parties, immigration is a somewhat troubling topic, as the public's stances are moderate, though reserved and slightly more negative in Finland than in other Nordic countries (EVA 2012; Himmelroos \& Leino 2015; Avonius \& Kestilä-Kekkonen 2018). As a political issue, immigration does not follow the traditional left - right divide, but instead has conflicting political implications (Odmalm 2011; see also Dennison \& Goodwin 2015). The Finns Party does not face this problem, as opposing immigration is one of its only uniting elements (Ylä-Anttila 2014).

Officials were the second-most-used group of interviewees in studio settings. They appeared in solo interviews more than any other interviewee group (see Figure 3). From this position, they appeared as conveyers of the truth (Horsti 2003), although officials represent their employers and, thus, have a certain professional rationale that impacts how they present their case (see e.g. Klocker \& Dunn 2003). In our case, officials discussed the same topic (i.e. the arrival of asylum-seekers) as experience experts, but from a different perspective. As previous research indicates, officials are usually used to bring a voice of authority to a news story (Horsti 2003; Dimitrova \& Strömbäck 2009). In this context, official interviewees - the most popular being representatives of the Finnish Immigration Service, the Ministry of the Interior and the police and border patrol - were used to provide updates on how infrastructure and processes were adjusted to handle the spike in asylum applications. In other words, the focus was on whether the situation was under control or not, and on the problems faced by the officials, as found in a previous case study by Horsti (2003).

Academic and other experts also played a visible role in the debates, but only a handful were scholars of immigration. As shown in previous research, academic or other experts were used more for commenting on and analysing current affairs than communicating their own research (Steele 1995; Albæk et al. 2003; Nord \& Strömbäck 2003; Albæk 2011; Wien 2014). The vast majority of academic researchers interviewed 
were social scientists who specialised in politics and the history of Finland, Europe, Russia and Turkey. Researchers were used to analysing the developing situation of the EU's inner decision-making, the negotiations between the EU and Turkey and the border conflict between Finland and Russia. They also focused on the domestic power play and public opinion.

In comparison, the larger context and long-term consequences of the situation were discussed less often; thus, scholars of immigration - or social geography or development studies - were largely ignored. In addition to theme selection, inappropriate and abusive audience feedback hinders the willingness of scholars to participate in live studio sessions on sensitive and controversial issues like immigration. For example, some female scholars have received threats of sexual violence following their public appearances (Pöyhtäri et al. 2013).

The composition and re-use of interviewees demonstrates how YLE relied on previously known academic sources (cf. Albæk 2011; Wien 2011; Parviainen 2014; Pitkänen $\&$ Niemi 2016). For example, within the academic and other expert category, ten people were interviewed more than once. The most commonly used group of experts were researchers from the Finnish Institute of Foreign Affairs, all of whom were experienced media commentators. Other experts were drawn from the largest university in southern Finland, with many publicly known from their previous media appearances. Status-wise, nearly half the academics were either professors or directors. As previous literature has demonstrated, a researcher's formal qualifications are not the only criteria for their selection; a good source must also be publicly recognisable and a good and eager communicator (Steele 1995; Conrad 1999; Niemi \& Pitkänen 2016; Pitkänen \& Niemi 2016).

Asylum-seekers, former asylum-seekers and other immigrants ("experience experts") comprised 11 per cent of all interviewees. This group of interviewees appeared mostly in short television inserts, not in the studio. The hierarchy between elite and grassroots sources detected in this study has previously been found in other studies (e.g. Hackett 1985; Cross 2010). As Cross (2010: 424) describes, the short time given to ordinary people - or, in this instance, asylum-seekers - makes them "fillers" in the larger news story. Furthermore, when asylum-seekers were interviewed, the focus was on their life stories: why they had left, how they arrived in Finland, their lives in the reception centres and their hopes for the future.

The same tendency to acknowledge asylum-seekers and minorities as experts only of their own life stories, cultures and religions has also been found in previous studies (Buchanan et al. 2003; Raittila \& Vehmas 2005; Gross et al. 2007; Richardson 2010; Haavisto 2011; Berry et al. 2015). For example, in interviews by Gross et al. (2007), most journalists considered asylum-seekers and refugees appropriate sources only in human interest stories, and certainly not suitable to comment on policies affecting them. The journalists interviewed also reported access, language and the possible negative consequences for the asylum-seekers as hindrances to using them as sources.

Figure 4 shows the proportion of males and females with regard to the different categories of interviewees.

In terms of gender and ethnic background, the interviewees were predominantly male and ethnic Finns, as found in previous studies (Ghersetti 2001; Wien 2011; Parviainen 2014; Kulneff \& Niemi \& Pitkänen 2016; Cedersjö 2017). As seen in Figure 4, over 60 per cent of the interviewees were men. The most male-dominated groups were the two 
Figure 4. Interviewees by gender (per cent)

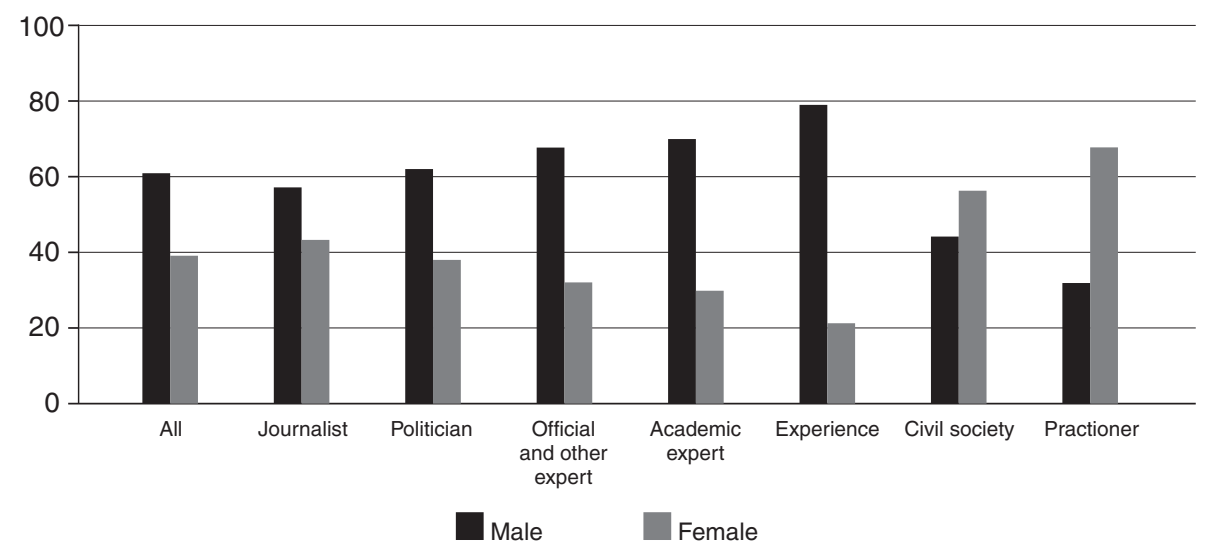

Comments: In total, 549 interviewees were coded.

groups of experts, experience experts and the group of academics and other experts. In contrast, the practitioners and members of civil society were mostly women.

While the share of female politicians reflects the composition of parliament, female experts were underrepresented, as women constitute more than half the academics in the largest universities, especially in the field of social sciences (University of Helsinki 2013; University of Turku 2015; University of Tampere 2016). Within the category of officials, the male-dominated terrains of policing and border control contributed to the gender gap.

Figure 5. Interviewees by ethnicity (per cent)

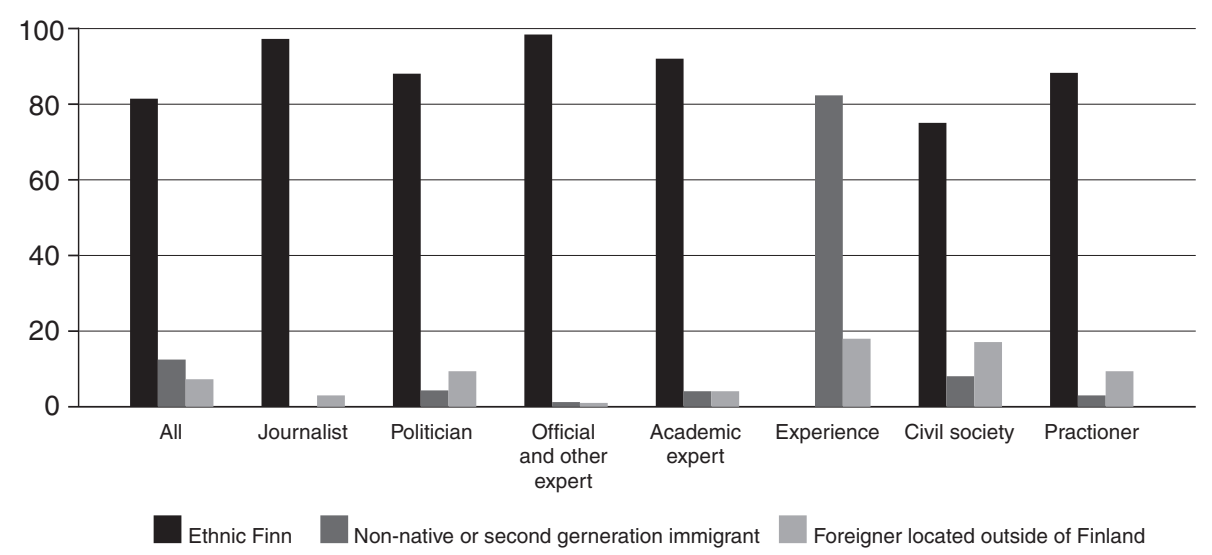

Comments: In total, 549 interviewees were coded.

As seen in Figure 5, ethnic Finns constituted over 80 per cent of the interviewees. When television inserts and short phone interviews are excluded, this figure rises to over 90 per cent. In total, YLE interviewed 13 non-natives from outside the category of experience experts. In a way, this does reflect Finland's monoethnicity, but the overall topic here analysed could be said to require a more heterogeneous selection of interviewees. Finding new interviewees with more diverse ethnic backgrounds would have required 
extra time and effort from the journalists, however, and time, we know, is something that journalists today are often short of.

\section{Conclusion}

During the seven-month period studied, the asylum-seeker situation was YLE's number one news story, covered almost every other day. The situation was mostly framed as a European crisis, with coverage concentrating on how Finland could pull through the situation and how the situation would be solved at national and EU levels. In terms of interviewee selection, YLE followed the common media logic of relying on the most authoritative sources: politicians, officials and researchers (Hall et al. 1978). However, in the context of Finnish immigration journalism, the large-scale involvement of politicians was a new phenomenon. During the previous "asylum-seeker incident" in 1999, for example, though the media relied mostly on elite sources like officials, journalists interviewed only a couple politicians, and mainly the interior minister (Horsti 2003; see also monitoring studies by Raittila \& Vehmas 2005; Haavisto 2011; Vehmas 2012).

How can we explain the new role of Finnish politicians? We conclude that immigration has not traditionally been a major political issue in Finland, where the number of immigrants has traditionally been lower than in many other European countries, including other Nordic states (Himmelroos \& Leino 2015), and where political party perspectives on immigration were largely unanimous until the rise of the Finns Party in the late 2000s (for more detail, see Välimäki 2018). The 2015 asylum seekers situation, however, politicised the issue in a new way, as the unprecedented numbers of asylumseekers had political, cultural and practical implications that demanded politicians in the conversation. Furthermore, in the wake of the "crisis", the Finns Party gained a new position of power in Finnish politics by entering government for the first time in history. Among politicians, Finns Party politicians were the most commonly used group of interviewees. The party's overrepresentation in YLE's coverage is best explained by the party's distinct views, the media's convention of including opposing views, the party's issue ownership of immigration, its representatives' enthusiasm for joining the debate and the party's position of power as a governing party.

Amongst the most commonly used interviewee groups, the drive to use elite sources was slightly challenged. It is noteworthy that, compared to the other interviewees, who were mostly actors with high status and longer experience as politicians or officials, most Finns Party representatives had only a few months of parliamentary experience. For example, the (then) party leader and foreign minister, Timo Soini, did not appear in the conversations at all.

As predicted based on the findings of previous research, the voices of asylum-seekers were practically absent. In addition to experience experts, people working with asylumseekers, representatives of civil society and people with more diverse background were also underrepresented. Scholars of immigration and other fields tapping the core reasons for displacement and its wider implications for individuals and receiving countries were also absent from the conversation, although researchers in general were one of the most visible groups. This highlighted YLE's emphasis on domestic and European power plays over the other relevant perspective of the complex phenomenon of displacement of people. Furthermore, the marginal position of grassroots actors raises critical ques- 
tions concerning the consequences of giving a voice to some, but not others. As pointed out by Horsti and Nikunen (2013), by excluding immigrants and activists supporting a multicultural society, the media gives prominence to the anti-immigrant argument and creates a view of a nation without a grassroots multi-ethnic life.

The situation revealed in this study reflects the wider underrepresentation of women and immigrants in media debates, which stems from fundamental values and the journalistic work culture. Difficulties related to access and communication can hinder efforts to include foreign-born people or people seen as "others", regardless of their nationality or origin. Whose voice needs to be heard, and how much work and effort should be allocated to ensure that different segments of society are included in public debate? Language will remain a barrier, for example, as long as there is a lack of willingness to look harder for interviewees, to use translators during programmes or to record programmes in advance to add subtitles. In addition to simply look at the quantity of minority interviewees, we should also consider the types of role in which they appear. As noted, experience experts were used primarily as "fillers" in inserts, and no experience experts and only 13 other non-natives were interviewed in studio settings. We can conclude from this that YLE's dedication to cultural exchange and diversity is not fulfilled in its content.

\section{Notes}

1. Before 2015, the number of annual asylum seekers had been a few thousand or less (Välimäki 2018a). In terms of societal diversity, Finland is the most monoethnic Nordic nation, with immigrants and second-generation immigrants representing just above six per cent of the total population (Tilastokeskus 2015), and Finns' attitudes towards immigration are slightly more negative than those of their Nordic peers (Avonius \& Kestilä-Kekkonen 2018).

2. Due to demands from the Finns Party, "cultural diversity" replaced the previous wording of "multiculturalism" in the summer of 2016.

3. Of the governing parties, most coverage was given to the Finns Party, with 25 per cent of all politician guests.

\section{References}

Albæk, Erik (2011). The Interaction Between Experts and Journalists in News Journalism. Journalism, 12(3): 335-348.

Albæk, Erik; Christiansen, Peter Munk \& Togeby, Lise (2003). Experts in the Mass Media: Researchers as Sources in Danish Daily Newspapers, 1961-2001. Journalism \& Mass Communication Quarterly, 80(4): 937-948.

Avonius, Marja \& Kestilä-Kekkonen, Elina (2018). Suomalaisten maltilliset ja kirjavat maahanmuuttoasenteet [The Moderate and Colourful Immigration Attitudes of Finns]. Yhteiskuntapolitiikka 83(1): 84-95.

Balch, Alex \& Balabanova, Ekaterina (2011). A System in Chaos? Knowledge and Sense-making on Immigration Policy in Public Debates. Media, Culture \& Society, 33(6): 885-904.

Balch, Alex \& Balabanova, Ekaterina (2014). Ethics, Politics and Migration: Public Debates on the Free Movement of Romanians and Bulgarians in the UK, 2006-2013. Politics, 36(1): 19-35.

Balfour, Rosa; Emmanouilidis, Janis; Fieschi, Catherine; Grabbe, Heather; Hill, Christopher; Lochocki, Timo; Mendras, Marie; Mudde, Cas; Niemi, Mari K \& Schmidt, Juliane (2016). Europe's Troublemakers. The Populist Challenge to Foreign Policy. Brussels: European Policy Centre.

Berry, Mike; Garcia-Blanco, Inaki \& Moore, Kerry (eds.) (2015). Press Coverage of the Refugee and Migrant Crisis in the EU: A Content Analysis of Five European Countries. Geneva: UNHCR.

Blinder, Scott \& Allen, William (2016). Constructing Immigrants: Portrayals of Migrant Groups in British National Newspapers, 2010-2012. International Migration Review, 50(1): 3-40.

Buchanan, Sara; Grillo, Bethan; Threadgold, Terry \& Wengraf, Tom (2003). What's the Story? Results from Research Into Media Coverage of Refugees and Asylum Seekers in the UK. London: Article 19. 
Conrad, Peter (1999). Uses of Expertise: Sources, Quotes, and Voice in the Reporting of Genetics in the News. Public Understanding of Science, 8(4): 285-302.

Cross, Kathleen Ann (2010). Experts in the News: The Differential Use of Sources in Election Television News. Canadian Journal of Communication, 35(3): 413-429.

Curran, James (2002). Media and Power. London: Routledge.

Dennison, James \& Goodwin, Matthew (2015). Immigration, Issue Ownership and the Rise of UKIP. Britain Votes, 68(suppl 1): 168-187.

Dimitrova, Daniela \& Strömbäck, Jesper (2009). Look Who's Talking: Use of Sources in Newspaper Coverage in Sweden and the United States. Journalism Practice, 3(1): 75-91.

Entman, Robert (2004). Projections of Power: Framing News, Public Opinion, and US Foreign Policy. Chicago: University of Chicago Press.

Eurostat (2016). Record number of over 1.2 million first time asylum seekers registered in 2015. [online]. Available at <http://ec.europa.eu/eurostat/documents/2995521/7203832/3-04032016-AP-EN. pdf/790eba01-381c-4163-bcd2-a54959b99ed6>. [Accessed 30 May, 2017].

Finnish Immigration Service (2017). Maahanmuuttoviraston vuoden 2016 tilastot [The statistics of the Finnish Immigration Service from the year 2016]. [online]. Accessed at $<$ http://migri.fi/artikkeli/-/asset_publisher/ maahanmuuttoviraston-vuoden-2016-tilastot-paatoksia-tehtiin-ennatysmaara $>$. [Accessed 30 May, 2017].

Finnpanel (2015). Katsotuimpien ohjelmien TOP-listat [The top rankings of the most watched programmes]. [online]. Accessed at $<$ https://www.finnpanel.fi/tulokset/tv/vuosi/top/2015/>. [Accessed 30 May, 2017].

EVA (2012). Ovi raottuu - Suomalaisten maahanmuuttoasenteet 2012 [Door opens a bit: The immigration attitudes of Finns]. Helsinki: Elinkeinoelämän valtuuskunta.

Gabrielatos, Costas \& Baker, Paul (2008) Fleeing, Sneaking, Flooding: A Corpus Analysis of Discursive Constructions of Refugees and Asylum Seekers in the UK Press, 1996-2005. Journal of Englsih Linquistics, 36(1): 5-38.

Ghersetti, Marina (2001). Personer med invandrarbakgrund i Rapport, Aktuellt, Sportnytt, Kulturnyheterna. Göteborg: Göteborgs universitet.

Gross, Bernhard; Moore, Kerry \& Threadgold, Terry Roslyn (2007). Broadcast News Coverage of Asylum April to October 2006: Caught Between Human Rights and Public Safety. Cardiff: Cardiff University.

Haavisto, Camilla (2011). Conditionally One of "Us": A Study of Print Media, Minorities and Positioning Practices. Helsinki: University of Helsinki.

Hackett, Robert (1985). A Hierarchy of Access: Aspects of Source Bias in Canadian TV News. Journalism Quarterly, 62(2): 256-265.

Hall, Stuart; Critcher, Chas; Jefferson, Tony; Clarke, John \& Roberts, Brian (1978). Policing the Crisis: Mugging, the State, and Law and Order. London: Macmillan.

Hatakka, Niko; Niemi, Mari \& Välimäki, Matti (2017). Confrontational Yet Submissive: Calculated Ambivalence and Populist Parties' Strategies of Responding to Racism Accusations in the Media. Discourse \& Society, 28(3): 262-280.

Hellström, Anders; Nilsson, Tom \& Stoltz, Pauline (2012). Nationalism vs. Nationalism: The Challenge of the Sweden Democrats in the Swedish Public Debate. Government and Opposition, 47(2): 186-205.

Himmelroos, Staffan \& Leino, Mikko (2015) Does the Neighbourhood Context Explain Attitudes Towards Immigration? A Study of Opinion in the City of Turku, Finland. Research of Finnish Society 8(1): 33-45.

Horsti, Karina (2003). Global Mobility and the Media. Nordicom Review, 24(1): 41-54.

Horsti, Karina (2005). Vierauden rajat: Monikulttuurisuus ja turvapaikanhakijat journalismissa [Limits of unfamiliarity: Multiculturalism and asylum seekers in journalism]. Tampere: Tampere University Press.

Horsti, Karina (2008). Europeanisation of Public Debate: Swedish and Finnish News on African Migration to Spain. Javnost, 15(4): 41-53.

Horsti, Karina \& Nikunen, Kaarina (2013). The Ethics of Hospitality in Changing Journalism: A Response to the Rise of the Anti-Immigrant Movement in Finnish Media Publicity. European Journal of Cultural Studies, 16(4): 489-504.

Innes, Alexandria (2010). When the Threatened Become the Threat: The Construction of Asylum Seekers in British Media Narratives. International Relations, 24(4): 546-577.

Jungar, Ann-Cathrine (2016). From Mainstream to the Margin? The Radicalisation of the True Finns. In Tjitske Akkerman, Sarah L de Lange \& Matthijs Rooduijn (eds.), Radical Right-Wing Populist Parties in Western Europe: Into the Mainstream? (pp. 113-143) London: Routledge.

Keskinen, Suvi (2009). Pelkkiä ongelmia? Maahanmuutto poliittisen keskustelun kohteena [Just problems? Immigration as the object of political debate]. In Suvi Keskinen, Anna Rastas \& Salla Tuori (eds.), En ole rasisti, mutta... Maahanmuutosta, monikulttuurisuudesta ja kritiikistä [I'm not racist, but ... On immigration, multiculturalism and criticism]. (pp. 33-45). Tampere: Vastapaino.

Khosravinik, Majid (2010). The Representation of Refugees, Asylum Seekers and Immigrants in British Newspapers. A Critical Discourse Analysis. Journal of Language and Politics, 9(1): 1-28. 
Klocker, Natascha \& Dunn, Kevin (2003). Who's Driving the Asylum Debate? Newspaper and Government Representations of Asylum Seekers. Media International Australia Incorporating Culture and Policy, 109(1): 71-92.

Kuckartz, Udo (2014). Qualitative Text Analysis: A Guide to Methods, Practice and Using Software. London: Sage.

Kulneff, Ebba \& Cedersjö, Johan (2017) Vem syns i medierna? Nya siffror visar fortsatt skev representation. Sverigeradio. [online]. Available at $<\mathrm{http}$ ://sverigesradio.se/sida/artikel.aspx?programid=2795\&artikel $=6822158>$. [Accessed 7 February, 2018].

McCombs, Maxwell (2004) Setting the Agenda: The Mass Media and Public Opinion. Cambridge: Polity Press.

McKay, Fiona; Thomas, Samantha \& Warwick Blood (2011). "Any One of these Boat People Could be a Terrorist For All We Know!” Media Representations and Public Perceptions of 'Boat People'Arrivals in Australia. Journalism, 12(5): 607-626.

Ministry of the Interior in Finland (2016). Rapid Increase in the number of asylum seekers. [online]. Available at $<$ www.intermin.fi/en/migration/refugees_and_asylum_seekers $>$. [Accessed 12 June, 2016].

Niemi, Mari \& Perälä, Annu (2018). Keiden ääni kuului, keiden "kriisistä” puhuttiin? Ylen journalistiset valinnat turvapaikanhakijoita käsittelevissä ohjelmissa [Whose voices were heard, whose 'crisis' discussed?: Yle's journalistic choises in magazine programmes dealing of asylum seekers]. In Niemi, Mari \& Houni, Topi (eds.) Media ja populismi: Työkaluja kriittiseen journalismiin [Media and populism: Tools for critical journalism] (pp. 146-172). Tampere: Vastapaino.

Niemi, Mari \& Pitkänen, Ville (2016). Gendered Use of Experts in the Media: Analysis of the Gender Gap in Finnish News Journalism. Public Understanding of Science, 26(3): 355-368.

Nord, Lars \& Strömbäck, Jesper (2003). Making Sense of Different Types of Crises: A Study on the Swedish Media Coverage of the Terror Attacks Against the United States and the U.S. Attacks in Afghanistan. Press/Politics, 8(4): 54-75.

Odmalm, Pontus (2011). Political Parties and "the Immigration Issue": Issue Ownership in Swedish Parliamentary Elections 1991-2010. Western European Politics, 34(5): 1070-1091.

Parker, Samuel (2015). "Unwanted Invaders": The Representation of Refugees and Asylum Seekers in the UK and Australian Print Media. Myth and Nation, 23(1): 1-21.

Parviainen, Aapo (2014). Mediassa paras ekonomisti on pankkiekonomisti [The best economist in media is a bank economist]. Kansantaloudellinen aikakauskirja, 110(4): 574-581.

Philo, Greg; Briant, Emma \& Donald, Pauline (2013). Bad News for Refugees. London: Pluto Press.

Pietikäinen, Sari (2000). Discourses of Differentiation: Ethnic Representations in Newspaper Texts. PhD Thesis, Jyväskylä: University of Jyväskylä.

Pitkänen, Ville \& Niemi, Mari (2016). Hallitsematon ja houkutteleva media: Yhteiskuntatieteilijöiden näkemyksiä julkisesta asiantuntijuudesta [An uncontrollable and attractive media: Social scientists' views on public expertise]. Yhteiskuntapolitiikka, 81(1): 5-16.

Pöyhtäri, Reeta; Haara, Paula \& Raittila, Pentti (2013). Vihapuhe sananvapautta kaventamassa [Hate speech narrowing the freedom of speech]. Tampere: Tampere University Press.

Raittila, Pentti (2009). Journalismin maahanmuuttokeskustelu: hymistelyä, kriittisyyttä vai rasismin tukemista [Immigration debate in journalism: humming, criticism or supporting racism]. In Suvi Keskinen (ed.), En ole rasisti, mutta ... Maahanmuutosta, monikulttuurisuudesta ja kritiikistä [I'm not racist, but ... On immigration, multiculturalism and criticism] (pp. 67-75). Tampere: Vastapaino.

Raittila, Pentti \& Vehmas, Susanna (2005). Etnisyys ja rasismi sanomalehdissä 1999-2004: Seurantatutkimusten yhteenvetoa ja arviointia [Ethnicity and racism in newspapers 1999-2004: Summary and evaluation of follow-up studies]. In Raittila, Pentti (ed.), Etnisyyttä, rasismia ja dialogia sanomalehdissä ja Internetissä. Tampere: Tampere University Press.

Rasinger, Sebastian (2010). "Lithuanian Migrants Send Crime Rocketing": Representation of "New" Migrants in Regional Print Media. Media, Culture \& Society, 32(6): 1021-1030.

Richardson, John (2010). Who Gets to Speak? A Study of Sources in the Broadsheet Press. In Poole, Elizabeth \& Richardson, John E (eds.), Muslims and the News Media (pp. 103-116). London: I. B. Tauris.

Saarikkomäki, Elsa; Oljakka, Nea; Vanto, Johanna; Pirjatanniemi, Elina; Lavapuro, Juha; Alvesalo-Kuusi, Anne (2018). Kansainvälistä suojelua koskevat päätökset Maahanmuuttovirastossa 2015-2017 [Decisions on humanitarian protection in The Finnish Immigration Office, 2015-2017]. [online]. Available at: <http:// www.utu.fi/fi/yksikot/law/tutkimus/katsauksia-ja-tutkimusraportteja/Documents/Kansainvalista $\% 20$ suojelua\%20koskevat\%20paatokset\%20Maahanmuuttovirastossa\%2022.3.2018.pdf $>$. [Accessed 27 of July, 2018].

Schlesinger, Phillip (1990). Rethinking the Sociology of Journalism: Source Strategies and the Limits of Media-Centrism. In Ferguson, Marjorie (ed.), Public Communications: The New Imperatives (pp. 61-83). London: Sage.

Schultz, Ida (2007). The Journalistic Gut Feeling. Journalism Practice, 2(1): 190-207. 
Steele, Janet (1995). Experts and the Operational Bias of Television news: The Case of the Persian Gulf War. J\&MC Quarterly, 72(4): 799-812.

Tilastokeskus (2015). Ulkomaalaistaustaiset. [online]. Available at <http:/www.stat.fi/tup/maahanmuutto/ maahanmuuttajat-vaestossa/ulkomaalaistaustaiset.html>. [Accessed 3 May, 2017].

Tressch, Anke (2009). Politicians in the Media: Determinants of Legislators' Presence and Prominence in Swiss Newspapers. International Journal of Press/Politics 14(1): 67-90.

University of Helsinki (2013). Vuosikertomus [Annual report]. [online]. Available at $<$ http://www.helsinki. fi/vuosikertomus2013/>. [Accessed 4, June 2017].

University of Tampere (2016). Henkilöstökertomus 2016 [Personnel report 2016]. [online]. Available at < https://www.uta.fi/sites/default/files/inline-files/henkilostokertomus2016_TaY.pdf>. [Accessed 4, June 2017].

University of Turku (2015). Henkilöstökertomus [Personnel report]. [online]. Available at $<$ https://www.utu.fi/ fi/Yliopisto/Documents/Turun_yliopiston_henkil\%C3\%B6st\%C3\%B6kertomus_2015.pdf $>$. [Accessed 3 June, 2017].

Vehmas, Susanna (2012). Maahanmuuttokirjoittelu sanomalehdissä [Writing on immigration in newspapers]. In Mari, Maasilta (ed.), Maahanmuutto, Media ja Eduskuntavaalit [Immigration, media and parliamentary elections] (pp. 116-135). Tampere: Tampere University Press.

Wien, Charlotte (2014). Commentators on Daily News or Communicators of Scholarly Achievements? The Role of Researchers in Danish News Media. Journalism, 15(4): 427-445.

Vliegenthart, Rens \& van Zoonen, Liesbet (2011). Power to the Frame: Bringing Sociology Back to Frame Analysis. European Journal of Communication, 26(2): 101-115.

Välimäki, Matti (2018a-forthcoming). Kansainvälistä suojelua hakevia henkilöitä koskeva politiikka ja lainsäädäntö [Politics and legislation on people seeking for international protection]. In Eveliina Lyytinen (ed.), Turvapaikanhaku ja pakolaisuus Suomessa [Asylum seeking and being refugee in Finland]. (pp. $\mathrm{xx}-\mathrm{xx})$. Turku: Migration Institute of Finland.

Välimäki, Matti (2018b). Kansainvälisten muutosten puristuksessa: Keskustan, kokoomuksen ja sosiaalidemokraattien pakolaispolitiikka 1973-2015 [Under pressure from international deveploments: Refugee politics of the Centre Party, the National Coalition Party and the Social Democractic Party, 1973-2015].

Yilmaz, Ferruh (2012). Right-wing Hegemony and Immigration: How the Populist Far-Right Achieved Hegemony through the Immigration Debate. Current Sociology, 60(3): 368-381.

Yle (2015). KOURA Palkitsi vuoden 2014 parhaita ohjelmia [KOURA rewarded the best programmes of the year 2014. [online]. Accessed at $<$ https://yle.fi/aihe/artikkeli/2015/03/19/koura-palkitsi-vuoden-2014-parhaita-ohjelmia $>$. [Accessed 3 June, 2017].

Ylä-Anttila, Tuukka (2014). Perussuomalaisten sisäiset poliittiset suuntaukset: Julkisen oikeuttamisen analyysi. Politiikka, 56(3): 191-209.

ANNU PERÄLÄ, Phd Student, Department of Social Research, University of Turku, annu. perala@utu.fi

MARI K. NIEMI, PhD and Director of the InnoLab research platform at the University of Vaasa,mari.k.niemi@univaasa.fi 